УДК 373.2.017: 172.15]: 821

DOI https://doi.org/10.24919/2308-4863/34-3-31

Людмила ІЩЕНКО, orcid.org/0000-0003-3382-4148 доктор педагогічних наук, професор, завідувач кафедри психології та педагогіки розвитку дитини Уманського державного педагогічного університету імені Павла Тичини (Умань, Черкаська область, Украӥна) liskra118@gmail.com

Тетяна ЖУРАВКО, orcid.org/0000-0003-0717-900X викладач-стажист кафедри психологї та педагогіки розвитку дитини Уманського державного педагогічного університету імені Павла Тичини

(Умань, Черкаська область, Україна) tanazuravko1996@gmail.com

\title{
ХУДОЖНЕ СЛОВО ЯК ЗАСІБ ПАТРІОТИЧНОГО ВИХОВАННЯ ДІТЕЙ СТАРШОГО ДОШКІЛЬНОГО ВІКУ
}

У статті висвітлюється проблема патріотичного виховання дітей стариого дошкільного віку. Аналізуються нормативні документи щуодо патріотичного виховання дітей дошкільного віку. Мета статті-розкрити особливості патріотичного виховання дітей старшого дошкільного віку засобами художнього слова в освітньому середовищі закладу дошкільної освіти.

Здійснено аналіз психолого-педагогічної та методичної літератури із проблеми патріотичного виховання дітей старшого дошкільного віку в освітньому процесі закладу дошкільної освіти. Висвітлено погляди педагогагуманіста В. Сухомлинського на значення художнього слова у вихованні дитини.

Досліджено, ще патріотизм, як і інші якості особистості, починає формуватися в дошкільному дитинстві, у період надзвичайно активного розвитку дитини. 3'ясовано, щчо опанування рідної мови як засобу пізнання $і$ способу специфічного людського спілкування є найвагомішим досягненням дошкільного дитинства. Мова виступає «каналом зв 'язку» для одержсання інформації з немовних сфер буття, засобом пізнання світу від конкретно-чуттєвого до понятійно-абстрактного. Охарактеризовано, щцо патріотичне виховання засобами художнього слова реалізується в різних формах організаиї життєдіяльності дітей: на заняттях різних типів, під час проведення свят та розваг відповідної тематики, у бесідах, під час ігрової діяльності тощз.

Дочкільне дитинство є надзвичайно важливим періодом у становленні особистості. Саме в цей час формуються фундаментальні якості людини, основи світосприйняття, ставлення до себе та свого місия у світі. Це стає можливим завдяки інтенсивному розвитку фізіологічних та психологічних якостей дітей, тому, на нашу думку, період дошкільного дитинства є досить сенситивним для формування патріотичної свідомості.

Ефективний виховний вплив здійснює інтегрування змісту патріотичного виховання в різноманітні види дитячої діяльності, як-от: мовленнєва, трудова, творча й ігрова, у різноманітні заняття (розвиток мовлення, народознавство, образотворче мистецтвво, музичне виховання, свята, розваги й інші), які проводяться в освітньому середовищі закладу дошкільної освіти.

Ключові слова: художне слово, діти дошкільного віку, патріотичне виховання, патріотичні почуття, рідна мова, казка, пісня. 
Ludmila ISHCHENKO, orcid.org/0000-0003-3382-4148

Doctor of Pedagogical Sciences, Professor, Pavlo Tychyna Uman State Pedagogical University (Uman, Cherkasy region, Ukraine) tanazuravko1996@gmail.com

Tetiana ZHURAVKO, orcid.org/0000-0003-0717-900X Trainee Teacher at the Department of Psychology and Psychology of Child Development Pavlo Tychyna Uman State Pedagogical University (Uman, Cherkasy region, Ukraine) tanazuravko1996@gmail.com

\section{ARTISTIC WORD AS A MEANS OF PATRIOTIC UPBRINGING OF SENIOR PRESCHOOL AGE CHILDREN}

The article highlights the problem of patriotic upbringing of older preschool children. Normative documents on patriotic upbringing of preschool children are analyzed. The purpose of the article is to reveal the peculiarities of patriotic upbringing of children of senior preschool age by means of artistic word in the educational environment of ZDO.

The analysis of psychological-pedagogical and methodical literature on the problem of patriotic upbringing of children of senior preschool age in the educational process of preschool education is carried out. The views of the teacher-humanist V. Sukhomlynsky on the importance of the artistic word in the upbringing of a child are highlighted.

It is studied that patriotism, as well as other personality traits, begins to form in preschool childhood, during the period of extremely active development of the child. Mastering the native language as a means of cognition and a way of specific human communication has been found to be the most important achievement of preschool childhood. Language acts as a "communication channel" for obtaining information from non-verbal spheres of life, a means of knowing the world from concrete-sensory to conceptual-abstract. It is characterized that patriotic education by means of the artistic word is realized in various forms of organization of children's life: in classes of different types, during holidays and entertainments on relevant topics, in conversations, during play activities and so on.

Preschool childhood is an extremely important period in the formation of personality. It is at this time that the fundamental qualities of man, the foundations of worldview, attitude to themselves and their place in the world are formed. This is possible due to the intensive development of physiological and psychological qualities of children, so in our opinion, the period of preschool childhood is quite sensitive to the formation of patriotic consciousness.

Effective educational influence integrates the content of patriotic education into various types of children's activities, such as: speech, labor, creative and play and in various classes (speech development, ethnography, fine arts, music education, holidays, entertainment, etc.), which are held in the educational environment of ZDO.

Key words: artistic word, preschool children, patriotic upbringing, patriotic feelings, native language, fairy tale, song.

Постановка проблеми. Реалізація державності залежить від дієвої громадянської позиції кожного члена нашого суспільства. Тому найголовнішим завданням суспільства завжди було, є i буде виховання поколінь гуманістів і патріотів, для яких найвищим ідеалом є єдність особистих та національно-державних інтересів.

У Конституції України, Національній доктрині розвитку освіти України, Національній стратегії розвитку освіти в Україні на періоддо 2021 р., Законі України «Про освіту», програмі «Базовий компонент дошкільної освіти» й інших державних документах визначаються мета, зміст, компетентності й основні завдання виховання в дітей любові до Батьківщини, усвідомлення ними свого громадянського обов'язку, утвердження якостей громадянина - патріота України як світоглядного чинника.

Проблема патріотизму є актуальним об'єктом дослідження сучасної наукової думки. Ї̈̈ докладно розкрито у працях відомих вітчизняних учених- педагогів, зокрема: I. Беха, А. Бойко, П. Ігнатенка, О. Киричука, Н. Косарєва, О. Кузьменко, А. Корицької, В. Кузя, О. Пометун, О. Сухомлинської, К. Чорної та інших, які досліджували поняття «патріотизм». Учені І. Огієнко, В. Сухомлинський, К. Ушинський та інші у працях розглядали роль та значення рідної мови у вихованні людини, наголошували, що мова - це культура та результат духовного життя нації, кращий вчитель (Ігнатенко та ін., 1997: 45).

Патріотизм як моральна якість має інтегральний зміст. 3 огляду на це досить ефективний виховний вплив здійснює інтегрування змісту патріотичного виховання в різноманітні види дитячої діяльності, як-от: мовленнєва, трудова, творча й ігрова, у різноманітні заняття (розвиток мовлення, народознавство, образотворче мистецтво, музичне виховання, свята, розваги тощо), які проводяться в освітньому середовищі закладу дошкільної освіти (далі - ЗДО). 
Аналіз досліджень. Аналіз сучасних досліджень у галузі патріотичного виховання дітей дошкільного віку висвітлено в роботах таких науковців: Л. Артемової, А. Богуш, І. Бех, А. Виноградової, Т. Поніманської, К. Чорної та інших, що свідчать про інтенсивні пошуки вчених і практиків щодо оновлення змісту освіти з патріотичного виховання дітей, наступності в роботі ЗДО та сім’ї.

Психологічними дослідженнями доведено, що основою патріотичної поведінки в дошкільників $\epsilon$ відпрацьований механізм дії, формування систем умовних рефлексів. Тому, поруч із розширенням та поглибленням уявлень, переживань, О. Каплуновська акцентує увагу на необхідності вправляння дітей у посильних для них моральних вчинках і поведінці (Каплуновська, 2016: 6-7).

У низці досліджень пріоритетними $є$ особистість дитини й обгрунтування умов іiі розвитку. Науковці стверджують, що в дошкільний період життя дитини формуються патріотичні почуття. Серед сучасних засобів патріотичного виховання А. Богуш, Н. Гавриш, Т. Котик виокремлюють художнє слово, розвиток мовлення дітей.

Шляхи патріотичного виховання дошкільників у сучасних умовах мають проходити через збагачення їхнього світогляду певними знаннями, формування уявлення про суспільні явища і події, накопичення соціального досвіду життя в найближчому оточенні (сім'я, вулиця, місто (село, селище)), через залучення до його культури, родинних традицій (Каплуновська, 2016: 6-7).

I. Бех, К. Чорна стверджують, що «патріотичне виховання дітей - це комплексна, системна і цілеспрямована діяльність сім' 'і, школи, інших соціальних інститутів щодо формування в молодого покоління високої патріотичної свідомості, почуття вірності, любові до Батьківщини, турботи про благо свого народу, готовності до виконання громадянського і конституційного обов'язку із захисту національних інтересів, цілісності, незалежності України, сприяння становленню іiі як правової, демократичної, соціальної держави» (Бех, 2014: 8).

На думку I. Беха та К. Чорної, на початку молодшого шкільного віку шестирічні діти виділяють особисті цінності, відбувається їх емоційне освоєння, яке закріплюється в діяльності, поведінці та міжособистісних взаєминах. У шестирічних дітей 3'являється дистанція соціальних зв'язків у процесі оцінювання норм поведінки дітей і дорослих; у них розвиваються певна орієнтація на соціум, уміння на відповідному рівні розуміти й оцінювати суспільні відносини. У шість років дитина починає розуміти важливість суспільно значу- щих справ, у неї формуються розуміння й оцінка соціальних явищ, орієнтація на оцінне ставлення дорослого крізь призму конкретної діяльності (Бех, Чорна, 2014: 11-25).

Мета статті - розкрити особливості патріотичного виховання дітей старшого дошкільного віку засобами художньої літератури.

Виклад основного матеріалу. До проблем виховання молодого покоління на засадах патріотизму в різні часи зверталися такі класики педагогічної науки, як: Г. Сковорода, К. Ушинський, С. Русова, А. Макаренко, В. Сухомлинський, Г. Ващенко й інші видатні вчені.

Виховними цілями вивчення рідної мови є формування «морально-етичних навичок поведінки, розвиток почуття любові до рідної землі, поваги до українського народу, цікавості до його мови, культури, літератури, звичаїв, традицій». I перша роль у здійсненні всіх цих програмних завдань належить вихователю, який сам повинен бути патріотом України, працювати не із примусу, а за покликанням свого серця, словом, у всьому служити взірцем високої моральності для своїх вихованців.

Важливу роль у вихованні молодої особистості відіграє дитяча література, яка є органічною і невід'ємною складовою частиною загальної літератури. Дитині, що тільки починає пізнавати навколишній світ, дуже потрібні книги, які готують іiі до активного життя в суспільстві. Твори дитячої літератури, які проходять крізь уяву i серце юного читача, збуджують у ньому співчуття до доброго і прекрасного, розширюють загальний кругозір, вчать любові й відданості, стійкості й незламності, чесності й наполегливості.

Відомий педагог К. Ушинський зазначав, що патріотичне виховання починається саме 3 рідної мови. Важливу роль у цьому процесі відіграє методика виховання у школі. Як казав К. Ушинський, «чим повніше і розумніше школа буде будувати свою роботу на основах народності, тим ближче стане вона до життя свого народу і буде краще виконувати своє завдання - готувати патріотів» (Ушинський, 1996: 193).

Особливо цінною для сучасної практики $є$ педагогічна спадщина відомого українського педагога-гуманіста В. Сухомлинського. Запропоновані ним форми і методи освітнього впливу на дитячу особистість залишаються актуальними в сучасній дошкільній освіті. Він убачав пріоритет у формуванні нового покоління свідомої молоді, вихованні патріотів, які по-справжньому люблять Батьківщину, горді за свій народ та його історичне минуле, відповідальні за його майбутнє. 
Головну роль у формуванні патріотичної свідомості В. Сухомлинський надавав рідній мові і рідному слову. Він підкреслював, що мова - то бездонна криниця, але треба дбати, щоб вона завжди була чистою, щоб багатство рідної мови було відкрито для дітей. Керуючись цими положеннями, особливих зусиль треба докладати до заохочування дошкільників вивчати рідну мову. Намагатися привернути їхню увагу до мелодійності української мови, іiї різнобарвності. Із цією метою використовувати народні прислів'я, приказки, пісні, колисанки, лічилки тощо (Сухомлинський, 1976: 167).

Любов до Батьківщини неможлива без любові до рідного слова: «Тільки той може осягнути своїм розумом і серцем красу, велич і могутність Батьківщини, хто збагнув відтінки й пахощі рідного слова, хто дорожить ним, як честю рідної матері, як колискою, як добрим ім'ям своєї родини $<\ldots>>$ > (Сухомлинський, 1976: 167).

Звідси випливає перше й головне завдання у вихованні молодого покоління - прищепити з раннього дитинства любов до рідної мови, щоб рідне слово жило й грало усіма барвами й відтінками в душі молодої людини, говорило їй про віковічні багатства народу, про красу «рідної землі, про народні ідеали й прагнення». Педагог має зробити рідне слово надбанням духовного світу дитини, тобто разом із звучанням рідного слова влити в молоду душу відчуття краси й емоцій, які вклав народ у слово. В. Сухомлинський уважає, що найлегше це зробити в ранньому дошкільному віці, оскільки дитяча душа надзвичайно чутлива до тонкощів краси й емоційного забарвлення рідного слова, адже дитинство - це не підготовка до життя, а «справжнє, яскраве, самобутнє, неповторне життя». Саме від того, що ввійде в період дитинства в розум і серце дитини 3 навколишнього світу, залежить, якою людиною вона стане завтра (Сухомлинський, 1976: 167).

Учений виокремлює також шляхи виховання любові до рідного слова в дітей на етапі дошкільного дитинства. Це насамперед любов до материнської пісні, материнського слова, хатньої близької і рідної для дитини мови. Народна дидактика здавна використовувала рідну мову як провідний засіб виховання дітей. Немає народу, байдужого до материнської мови, рідного слова, рідної домівки і рідної землі.

У перші місяці життя немовляти над колискою схиляється мати і тихо наспівує ніжні мелодії колисанки, кожне слово якої переливається в дитину, стає ії надбанням. Рідна мова $є$ найважливішим, найбагатшим і найміцнішим зв'язком між нинішнім і майбутнім поколіннями народу. Звідси випливає принцип народності, який відбито в образі рідного слова. Мова - найкраща характеристика народу, тому твори українського фольклору $є$ одним із важливих засобів збагачення словника дітей.

Наріжним каменем лінгводидактичної спадщини вченого $є$ принцип національної спрямованості мовленнєвого розвитку дитини і навчання iii рідної мови, який тісно переплітається із принципом урахування вікових особливостей дитини. Опанування рідної мови, рідного слова започатковується в ранньому дитинстві, а вдосконалення іiі, засвоєння культури триває протягом усього життя.

Під час організації освітнього процесу з патріотичного виховання дітей старшого дошкільного віку широко застосовуються принципи. Охарактеризуємо їх.

Принцип сенсибілізащії духовного розвитку особистості реалізується через образ рідного слова. У статті «Рідне слово» В. Сухомлинський підкреслює, що «мова - духовне багатство народу», а мовна культура людини - це «дзеркало їі духовної культури», це образ іiі почуттів, думок, ставлення до інших, що передається у словах рідної мови, а рідна мова виховує національну психологію, національний характер, національну самостійність (Сухомлинський, 1976: 167).

Принцип інтеракиійної (взаємопов'язаної) діяльності в розвитку мовлення і навчання дітей рідної мови знайшов своє втілення у своєрідному підході В. Сухомлинського до навчання дітей розповідання і грамоти. Невимушенепід час екскурсії, спостережень у природі, діти малювали, складали розповіді, підписували малюнкилітерами, вчилися писати, читати, малювати, розповідати, а також любити й охороняти рідну природу, рідну землю.

Тісно взаємодіє 3 попереднім принципом принцип сенсорно-лінгвістичного розвитку та навчання дітей рідної мови. Багаторічний досвід роботи 3 дітьми переконав педагога в необхідності використання природи як сенсорної, чуттєвої основи мовленнєвого розвитку дітей, «споконвічного джерела дитячого розуму і розвитку мовлення» (Сухомлинський, 1976: 167).

Принцип емоційної насиченості й естетичної спрямованості мовленнєвого розвитку дітей. На глибоке переконання вченого, світ природи викликає у дітей глибокі емоційні переживання, учить бачити й відчувати красу рідного краю, яка не тільки збуджує дитячу думку, а й породжує їхню мовленнєву активність. У дні негоди таку саму емоційну насиченість, на думку В. Сухомлинського, варто забезпечити у шкільних кімна- 
тах, особливо для найменших дітей. Наприклад, створити спеціально обладнану кімнату казок.

Чудодійним методом розвитку мовлення дітей називає В. Сухомлинський казку. Це «ключик», за допомогою якого відкривається джерело народної мови, «<..> свіжий вітер, що роздмухує вогник дитячої думки і мовлення». Завдяки казці дитина пізнає світ не тільки розумом, а й серцем, відгукується на події та явища навколишнього світу, висловлює своє ставлення до них. Початкове ідейне виховання дитини відбувається також у казці. Казка - невичерпне джерело патріотичного виховання вже тому, що вона створена народом (Сухомлинський, 1976: 167).

Найбагатшим матеріалом для патріотичного виховання $\epsilon$ твори усної народної творчості, які не тільки формують любов до традицій свого народу, а й сприяють розвитку особистості в дусі патріотизму. До старшого дошкільного віку діти вже знайомі з багатьма видами усної народної творчості, стають популярні лічилки, загадки, скоромовки, чарівні казки. (Діти переказують, інсценують, самі вигадують). Варто враховувати, що для знайомства 3 рідною культурою важливо не тільки, щоб дитина пасивно знала якийсь набір приказок і примовок, але щоб вони використовувалися нею у відповідних випадках - в іграх або обрядах.

Українські народні чарівні казки повні чудесного вимислу, драматичних ситуацій, протистояння добра і зла, не тільки розважають, радують дітей, а й формують основи моральності. Захоплення, здивування і повагу викликають у дітей розповіді про різні професії, особливо ті, з якими вони ще не були знайомі у своєму повсякденному житті, як-от полярники, мандрівники, вчені, військові, пожежники, космонавти. Знання про різні можливості проявити свою мужність і героїзм надихають дітей, виховують у них прагнення опанувати «героїчну» професією, служити людям і Батьківщині. (Діти хочуть бути льотчиками, космонавтами, військовими $<\ldots>$ ).

Оскільки прислів'я і приказки включають аксіологічний компонент, тобто дають оцінку поведінки дії, характеру, то ми використовували вирази не лише у процесі організаційних педагогічних ситуацій, але і в повсякденному спілкуванні, коли поведінка дітей була не регламентованою, невимушеною. Ми акцентували увагу на розвитку в дітей емоційного сприйняття приказок і прислів 'їв, ціннісного ставлення до їхнього змісту. Так, везіння виражалося у приказці «на ловця і звір біжить». Дошкільнята виділяли стилістичні відтінки, які виражали розмовно-побутове ставлення до предмета мови («і ведмедя тан- цювати учать»), зневажливе («дурня не навчиш»), жартівливе або іронічне («якщо б тремтіти не умів, зовсім би замерзнув»), поблажливе («хвалилася синиця море підпалити»).

Активність дітей дошкільного віку допомагає в невимушеній атмосфері брати участь у діалогових формах навчання, у формуванні власної моделі міркування про мотивовані значення слів у прислів'ях, приказках, виявленні спільних моментів у порівнюваних виразах.

В освітньому процесі ЗДО різноманітні програми пропонують казки, оповідання, вірші, що мають велику виховну силу. Твори художньої літератури, що пронизують весь освітній процес, доцільно включати в різні види дитячої діяльності. Значення віршів, які діти на заняттях розучують, надзвичайно велике у вихованні патріотичних почуттів.

Формами роботи, які дозволяють здійснювати патріотичне виховання дітей, $\epsilon$ вирішення педагогічних проблем на основі художніх творів, 3 подальшим обговоренням їх, складання розповідей під впливом прочитаного, розігрування сценок. Дітей доцільно також спонукати до сюжетнорольових ігор, ігор-драматизацій.

Дорослий може активно брати участь у рольовій грі, у драматизації, розвазі, виконувати роль ведучого, глядача, режисера або виконавця. Діти небайдужі до того, чи бачить їх вихователь, чи помічає їхню гру. Вони дуже чутливі до його реакції, якщо вихователь підтримує, схвалює їхні дії, активність дітей зростає, доброзичливі зауваження, підказка сприймаються як належне.

Виховання патріотичних почуттів буде ефективним за умови створення розвивального освітнього середовища, мета якого полягає в реалізації таких завдань:

- формувати в дітей позитивний образ Батьківщини та рідної домівки;

- виховувати любов і повагу до членів своєї родини, бажання піклуватися про них;

- формувати ціннісне ставлення до культури українського народу, його історичного минулого, мови, звичаїв, традицій;

- виховувати почуття власної гідності як представників свого народу;

- формувати толерантне ставлення до представників інших національностей, до ровесників, батьків, сусідів, інших людей.

Однією 3 умов формування патріотичних почуттів дітей старшого дошкільного віку $\epsilon$ проведення святково-ігрового дозвілля, яким служить повноцінно організоване розвивальне середовище. 
Велике значення має активна різноманітна діяльність дошкільнят, оскільки бути патріотом - це не тільки знати і любити свою країну, але і активно діяти на її благо. Для цього використовуються різні тематичні форми організації діяльності дітей, спрямовані на підвищення дитячої розумової активності. Цьому допомагають прийоми порівняння, питання, індивідуальні завдання, звернення до досвіду дітей. Необхідно привчати їх самостійно аналізувати побачене, робити узагальнення, висновки (можна запропонувати пошукати відповідь в ілюстраціях, запитати в батьків тощо). Сутність виховання патріотизму полягає в тому, щоб «завести» у дитини «внутрішній механізм», сформувати чуйність, образну уяву, винахідливість, спритність, застосовувати водночас необхідні засоби впливу на емоційно-чуттєву сферу (Богуш, 2002: 45).

Отже, постійне вправляння дітей у застосуванні художнього слова відіграє вагому роль у процесі формування цінностей, яке активно впливає на почуття і розум дитини, розвиває іï емпатійність, емоційність. Забезпечує розуміння і прийняття моральних норм як єдиних правильних варіантів поведінки. Художне слово приводить до великих змін в емоційній сфері дитини, сприяе появі живого відгуку, змінює ставлення до речей, перебудовує суб'єктивний світогляд. Необмежені можливості формування моральних цінностей i емоційного розвитку мають такі перлини народної творчості, як казки, байки, прислів'я, вірші тощо. У творах фольклору через його героїв яскраво постає ідеал українського виховання: здорова, гуманна, культурна, щаслива людина; вільна, оригінальна та неповторна особистість. Занурюючись у казковий світ, дитина занурюється у глибини своєї душі, вчиться опановувати цей підсвідомий простір. Повернувшись до реального світу, вона почувається впевненіше, починає усвідомлювати власну спроможність упоратися з очікуваними труднощами. Байки тактовно висміюють негативні якості характеру, навчають ставитись із гумором до життя, містять повчальний зміст. Поетичні твори мають велику силу впливу на емоційний розвиток та засвоєння ціннісних орієнтацій.

Висновки. У процесі патріотичного виховання засобами мови, художнього слова формуються складники патріотичної вихованості, які грунтуються на життєвих стереотипах українського народу й узгоджуються з народними уявленнями про високі виміри морального, естетичного, етичного, духовного, гуманістичного, відображають національний менталітет.

Варто впроваджувати у практику патріотичного виховання такі реконструйовані форми роботи, адаптовані до дітей старшого дошкільного віку: воркшопи, дитячі дайджести, національно-патріотичні, тренінгові заняття з розвитку міжнаціональної толерантності дітей, культурні проєкти, інтерактивно-мультимедійні студії, етнографічні райтси тощо.

Методичне забезпечення виховання патріотичних почуттів засобами рідної мовив вбачаємо у створені в закладі дошкільної освіти сучасного освітньо-виховного середовища патріотичного спрямування.

\section{СПИСОК ВИКОРИСТАНИХ ДЖЕРЕЛ}

1. Бех І. Програма патріотичного виховання дітей та учнівської молоді. Київ, 2014. 29 с.

2. Бех І., Чорна К. Програма українського патріотичного виховання дітей та учнівської молоді. Memoдист. 2014. № 11 (35). С. 11-25.

3. Богуш А. Українське народознавство в дошкільному закладі : навчальний посібник для студентів вищих педагогічних навчальних закладів. 2-е вид., перероб. і доп. Київ : Вища школа, 2002. 408 с.

4. Виховання громадянина: Психолого-педагогічний і народознавчий аспекти : навчально-методичний посібник / П. Ігнатенко та ін. Київ : Інститут змісту і методів навчання, 1997. С. 45.

5. Каплуновська О. Україна - моя Батьківщина. Парціальна програма національно-патріотичного виховання дітей дошкільного віку. Тернопіль : Мандрівець, 2016. С. 6-7.

6. Сухомлинський В. Як виховати справжню людину. Вибрані твори : у 5 т. / В. Сухомлинський. Київ : Радянська школа, 1976. Т. 2. С. 167.

7. Ушинський К. Про користь педагогічної літератури. Москва : Педагогіка, 1996. С. 193.

\section{REFERENCES}

1. Beh, I. D. Programa patriotychnogo vyhovannja ditej ta uchnivs'koi' molodi [The program patriotic education of children and young]. Kyiv. 2014. 29 p. [in Ukrainian].

2. Beh, I. D., Chorna, K. I. Programa ukrai'ns'kogo patriotychnogo vyhovannja ditej ta uchnivs'koi' molodi [The program of Ukrainian patriotic education of children and young]. Metodyst. 2014. № 11 (35). P. 11-25 [in Ukrainian].

3. Bogush, A. M. Ukrai'ns'ke narodoznavstvo v doshkil'nomu zakladi : navch. posib. dlja stud. vyshh. ped. navch. Zakl [Ukrainian studies in pre-school institution: textbook. guidances. for Stud. visch. EDR. textbook. spells.]. 2-e vyd., pererob. i dop. Kyiv : Vyshha shk. 2002. P. 408 [in Ukrainian]. 
Ішенко $\Lambda .$, Журавко Т. Художнє слово як засіБ патріотичного виховання ...

4. Ihnatenko P. R., Popluzhnyi V. L., Kosarieva N. I., Krytska L. V. Vykhovannia hromadianyna: [Citizen education: Psychological, pedagogical and ethnographic aspects]. Psykholoho-pedahohichnyi i narodoznavchyi aspekty: Navchalno-metodychnyi posibnyk. Kyiv : Instytut zmistu i metodiv navchannia. 1997. P. 45 [in Ukrainian].

5. Kaplunovska O. Ukraina - moia Batkivshchyna. [Ukraine is my motherland]. Partsialna prohrama natsionalno-patriotychnoho vykhovannia ditei doshkilnoho viku. Ternopil : Mandrivets, 2016. P. 6-7 [in Ukrainian].

6. Suhomlyns'kyj, V. O. Jak vyhovaty spravzhnju ljudynu [How to bring up a real person]. Vybr. tv.: v 5 t. Kyiv: Rad. shk. 1976. T. 2. P. 167 [in Ukrainian].

7. Ushynskyi K. D. Pro koryst pedahohichnoi literatury. [On the benefits of pedagogical literature]. M.: Pedahohika, 1996. P. 193 [in Russia]. 